\title{
Various Difficulties for International Students in Adjusting to a New Academic Culture When Studying Abroad
}

Xuejuan Luo

Qinghai Nationalities University, Xining, 810007, China

Keywords: Cultural shock. Adjust to. International students. Academic success

\begin{abstract}
Culture shock is a kind of psychological condition which sometimes may cause people's physical effects. It not only affects people who have been away from a surrounding where they have lived for a long time into a new environment where everything is new and different for them and they are not familiar with, including the food, weather, language, and typically the social rules and conventions for that they are not consciously aware of. However, it's for certain that everyone can succeed in the cross-cultural communication if he/she is ready for the incoming problems of cultural shock and enjoy a lot the process of living in a new culture with smile on the face. Nothing is difficult in this world if we dare face it.
\end{abstract}

Culture shock is first proposed by the world famous cultural anthropologist Kalvero Oberg. According to him, culture shock is the deep psychological anxiety because of the loss of one's own social communication signal or symbol. In the cross culture management, when people are abroad to work, study or settle in, they often experience different psychological reaction. There will be the beginning of the time of excitement period. At this time, people feel fresh and stimulating. However, after this excitement period, people will enter the culture shock period. This psychological is known as "culture shock". Culture shock theory refers to living in or experience a new culture or not a pleasant surprise or shock. The surprise or shock part is the person or thing in some sources which they do not expect a new environment as a result of a new negative culture evaluation of the sojourners.

People may experience four stages in cultural shock: the honeymoon stage, depression or hostile stage, stage of recovery and adjustment or adaptation stage. In the process of "going out", if people do not recognize and get across the "culture shock" correctly, not only will they suffer huge economic losses, waste a lot of time on academic study, at the same time, psychologically their family is difficult to heal wounds.

The reasons that cause those kinds of cultural differences can be stated as firstly, in the exotic culture a person loses his/her native culture around in the original social role, causing emotional instability. Secondly, contradictions and conflicts between two different values in the long period of the formation of cultural values and some values of exotic cultures are not in harmony due to not knowing what course to take. Thirdly, lifestyle, exotic cultures, habits and customs, and other different aspects of the society make people feel difficult to adapt to living in a foreign land. Along with the fast development of the globalization, the western society and things are more and more into our field of vision. In this case, the cross domain, cross national, cross-cultural economy and social exchanges will grow with each passing day. It provides a lot of contact with westerners and communication opportunities for us. This is a good thing for deepening our understanding of Western society. But this is not a simple thing, because what we face is from a strange society and a new culture, and we have to meet totally different ways of thinking, habits and behavior of the people. In association with the inevitable new environment it will appear the phenomenon of the cultural conflict. The analysis of the causes of the cultural conflict from different angles is mostly necessary. The most positive method, the effective coping with the cultural conflicts, is the process of how to deal with the cultural conflict to cultivate and enhance the intercultural communicative competence. At the same time, second language learning is of great significance for successful intercultural communication. 
This paper is designed to help the cross-cultural communicators to overcome the fear and anxiety in the face of foreign culture, so that they understand the differences between different cultures. Participants from the comparison between different culture perspectives examine the differences between one's own culture and Western culture. They construct the intercultural communication schema of their own and take some measures to develop the intercultural communication, so as to effectively overcome the barriers in cross-cultural communication.

International students may face various difficulties in adjusting to a new academic culture when studying abroad, particularly in the area of language, having different teaching styles and grading requirements, and thinking and writing in the western culture. However, at the same time, there are many ways in which these difficulties may be overcome, such as having activities, adjusting to the new assessment systems, improving knowledge and language level.

First, language is a big problem for international students. Oberg (1984) has described: "the travelers find it difficult to accomplish simple tasks in a new country with an unfamiliar language." They are afraid of communicating in English, since they are shy, nervous and speak in soft voice. Thus, they keep silent in group discussions, for instance, when the group discusses culture shock, they know that "sleeplessness at night," "changeable weather," "expensive transport," are all the symptoms of culture shock, yet they dare not express what they think. As (Barna, 1994) says: "the international student had been very serious about the whole subject but he was afraid he would say some thing wrong. He had the idea but not the words." Verbal skills such as, lack of vocabulary, poor understanding and hearing are other obstacles, which prevent them from communication. They can not find proper and correct words to express themselves even they know what they want to say according to (EL-Ters, 1993). Therefore, language is the first difficulty international students may face in Australia.

Second, overseas students usually are not used to the Australian style of teaching and assessment tasks. Teachers encourage students to be active in class by means of discussion and presentation. They are welcome to ask questions in class. However, some students pay attention to listen to the teacher and feel embarrassed to question and present themselves, as (Ponniahpillai, 1993) describes: "We are people who sit at the feet of the teacher, passively waiting to be taught...[and] don't know how to diagnose our needs for learning." Another problem is teachers' use of formal and technical words, which make them have troubles catching the main idea of a lecture, mentioned by (EL-Ters, 1993). Moreover, attendance and participation are important grading requirements. Sometimes students attend classes, but don't participate until they find it will do no good to their final term grades according to (Singh, 2000). Their Australian teachers may dismiss them as unpromising. Therefore, it will be helpful for international students if they can quickly adjust to the new teaching styles and assessment levels.

In addition, thinking and writing in the Australian culture can be extremely challenging for international students. Kaplan (1984) has argued: "different cultures produce distinctive approaches to thinking and writing." On the one hand, some students fail to fulfill their writing assignments just because they can not interpret the complex language of the question according to (Ponniaphillai, 1993). On the other hand, they have different thinking and writing purposes, as they have been trained in their own culture. Taking the Japanese student (Ballard \& Clanchy, 1984) for example, he was asked to discuss the different perspectives of two European postwar economists, but, instead, he described in detail their family life and when they published their works. Thus, the article was unacceptable because there was no relevance to the main points, no analysis, comparison and conclusion (Ballard \& Clanchy, 1984). It is obvious that the student arranged his points of view by following his Japanese writing style. Therefore,“[international students] have to learn to adjust [their] thinking and writing purposes and adapt the structure of [their] essays to meet the expectation of [their] lecturers"(Ballard \& Clanchy, 1984).

In spite of all these problems, overseas students can find ways to deal with them. First, they may try to improve their communication level by having various activities such as, being active in class discussions, attending public lectures and reports, going out to find part-time jobs and make friends. According to (Barna, 1994), “just as more opportunities now exist for cross-culture contact so does 
more information about how to meet this challenge." Second, they should try their best to follow the new teaching and assessment styles by not only coming to classes on time but also involving themselves in class activities, as Caldwell (1996) claims: "everyone is embarrassed when making a mistake; you can turn that mistake into the first step to your success." Furthermore, they should think to improve their knowledge and language level, change their way of thinking and writing through extensive reading, getting advice from tutors or doing self-research. As (Barna, 1994) suggests: “ A better approach is to begin by studying the history, political structure, art, literature and language of the country if time permits.” Through different reading materials students can gain wide range of knowledge and learn many verbal skills as well. Checking with tutors to get advice is the first step if they have questions in their academic research according to (Ponniahpillai, 1993). Finally, overseas students should spend more time conducting self-study, for instance, they may use library, Internet, tape, and radio searching skills of speaking, listening, reading, and writing.

According to those analyzed above, people should be aware that since the social environment is that the individual can't change, they should pay more attention to the cultural adjustment itself. Culture is the result of the human life experience and life experience as the foundation. Stimulation and the role of different living environment result in different feelings and opinions of people to the world outside itself. The thing to realize is that the major cultural transformation may generate pressure and tremendous anxiety, but stress and anxiety are the normal social adaptive consequence. When a person has "culture shock", and may thus have" xenophobia", he /she needs not only his/her self-esteem, confidence but also sincere good wishes and self image. Culture shock is not born, but the result of social and cultural environment. It is from the self standards of a cultural bias and psychological deviation caused by the heterogeneous culture criticism. As long as we look at different cultures with a horizontal view, will we be aware that this is only the sea rippling wave. A culture that for thousands of years can pass down, it must have its existence and heritage reasons. The only things we need to do is to take effort to actively adapt a new cultural environment, understand others, take practical strategies and always remember that any kind of serious "culture shock" and psychological "xenophobia" can be regarded as a new cultural experience and the psychological feeling. As the saying goes, "Do in Rome as the Roman do." people will gradually adapt to the diet and other problems of discomfort with the passage of time.

So, in conclusion, language, adjusting to different teaching styles, thinking and writing in the Australian culture are some of the major academic difficulties before international students when studying in Australia. However, at the same time, active participation, adjusting to new assessment systems, improving knowledge and language level are ways in which these problems may be solved. They can choose or find out what they think are useful and efficient solutions to meet their academic needs and achieve great success at last.

\section{References}

[1] Ballard, B. \& Clanchy, J.1984, Study aboard: A manual for Asian students, Longman, Malaysia.

[2] Barna 1994, Stumbling blocks in Intercultural communication, in Samovar, L\& Porter, R.1994. Intercultural Communication, ITP, Wadsworth.

[3] Caldwell 1996, Reaping the rewards of learning English, in Blandard, K. \& Root, C. 1996. For Your Information. Longman. NY.

[4] EL-Ters 1993, A student's problem, in VU English Language Institute, Essay \& Case Study Readings, UP2 2004, pp28-29.

[5] Kaplan 1984, Cultural thought patterns in inter-cultural education, in Ballard, B. \& Clanchy, J.1984, Study aboard: A manual for Asian students, Longman, Malaysia. 
[6] Oberg 1991,The stages of adjustment, in VU English language Institute, Essay \& Case Study Readings, UP2 2004, pp26-27.

[7] Ponniahpillai 1993, If in doubt, ask, in VU English language Institute, Essay \& Case Study Readings, UP2 2004, pp26-27.

[8] Singh 2000, Address to ISANA Members, on 18th October, University of Melbourne, Melbourne. 